\title{
LEADERSHIP ASPIRATIONS, ADMINISTRATION OF PERCEPTION AND ATTITUDE
}

\begin{tabular}{|c|c|c|c|}
\hline \multicolumn{4}{|c|}{$\begin{array}{c}\text { Sh. Sachin Gupta } \\
\text { SOMC, Sanskriti University, Mathura, Uttar Pradesh, India }\end{array}$} \\
\hline Journal & \multicolumn{3}{|c|}{$\begin{array}{l}\text { Samvakti Journal of Research in Business Management } \\
\text { https://www.sjrbm.samvaktijournals.com } \\
\text { Volume } 2 \text { Year of Volume } 2021 \text { Page No }: 25-32\end{array}$} \\
\hline Discipline & \multicolumn{3}{|c|}{ Business Management } \\
\hline Conference & \multicolumn{3}{|c|}{$\begin{array}{l}\text { A virtual international conference on redefining and transforming the role of higher } \\
\text { education in sustainable development }\end{array}$} \\
\hline Conference & \multicolumn{3}{|c|}{ Start Date: September 30, 2021} \\
\hline Dates & \multicolumn{3}{|c|}{ End Date : September 30, 2021} \\
\hline Institute Name & \multicolumn{3}{|c|}{$\begin{array}{l}\text { JAIN (Deemed-to-be University) in association with Council for Industrial } \\
\text { Innovation and Research }\end{array}$} \\
\hline $\begin{array}{l}\text { Date Received } \\
\text { ID } \\
\text { Dol }\end{array}$ & $\begin{array}{l}\text { : November } 19,2021 \\
: 2021.01 .15 \\
: 10.46402 / 2021.01 .15\end{array}$ & $\begin{array}{l}\text { Publication Date } \\
\text { Paper Type } \\
\text { Dol URL }\end{array}$ & $\begin{array}{l}\text { : December 12, } 2021 \\
\text { : Conference Paper } \\
\text { : https://dx.doi.org/10.46402/2021.01.15 }\end{array}$ \\
\hline
\end{tabular}

\section{ABSTRACT}

Although charisma is a critical component of transformative leadership, there are currently no reliable methods of forecasting leaders charm in an administrative setting, according to research. We may examine the various types of charisma as well as imprint organization of the two leaders, Steve Jobs as well as Bill Gates, by means of a qualitative-descriptive research. We look at the content of their public utterances to see if there are any common themes. Our findings support our hypothesis by revealing evidence that charisma is linked to higher power motivation as well as acquisitive imprint administration techniques. To be more explicit, we consider Steve Jobs to be a personal authority manager as well as Bill Gates to be a results-oriented manager. The ramifications for education are discussed.

KEYWORDS: Charisma, Charismatic Leaders, Impression Management, Motivation, Transformational Leadership. 


\section{INTRODUCTION}

In business, charismatic leadership is the single most significant predictor of positive results. There are only a few approaches for predicting charisma and, as a consequence, choosing charismatic leaders, particularly when considering the role of the leader's charismas in study as well as administrative performance. The motives of leaders, such as their desire for efficiency, power, and affiliation with others, have been studied for the first time in research on charismatic leadership and successful CEOs.

Other studies of change agents looked at skills including self-confidence, superiority, feminine qualities, pragmatism, and nurturance, as well as the emotional quotient, self-awareness, internal control locus, proactive personality, and cognitive capacity. Others have found links between transformational leadership and leadership principles, as well as moral reasoning and personal ethical preferences. We use a content examination approach created by D G. Winter to examine the motivations of two notable leaders, Steve $\mathrm{J}$ as well as Bill G. We find that the desire for immense power is linked to charisma, which is in line with earlier research ${ }^{[1]}$.

Furthermore, we demonstrate that acquisitive impression management tactics, rather than defensive measures such as ingratiation, self-promotion, intimidating, as well as exemplification, are more successful in enhancing a leader's charisma. We stress the need of firms engaging image management professionals to ensure that their representatives can project a heroics picture of themselves to the rest of the worlds. This is especially import ants for publics firms, whose market value is influenced by the views of their shareholders. Furthermore, the implications of these findings extend to the area of selection for human resource managers. In order to differentiate between different motivation profiles, we recommend that applicants' interview answers be scored using a scoring instrument.

\section{Transformational Leadership:}

The transformative leadership connection is described as a relationship wherein two or even more people interact with one another in such a manner that members and leaders both inspire and moralize each other. Transformational leaders' excellent behavior, altruistic attitude, inspiration, and high morals have a good influence on others around them. The culture of their companies is influenced by transformationalist leaders.

Idealised version power, motivational inspiration, as well as mental challenge, and customized attention are four components that contribute to transformative leadership. Idealized influence may be divided into 2 groups: idealized influences attribution and flawless influences behavior. Because transformational as well as charismatic leadership are considered identical twins, the terms transformational and charismatic leadership are often interchanged ${ }^{[2]}$.

Many academics have been studying charisma and charismatic leadership for quite some time. Max Weber, a German sociologist, is credited with being the first to use charisma in a leadership setting via his outstanding work. For him, the forces that collect and stabilize a community were fascinating. He came up with three ideal kinds to characterize the 
forces of specialist in a civilization: those who are traditionals, those who are logical and legal in their approach, and those who are charismatic in their approach.

A distinction was also made by Weber between pure charisma, which is an attribute of a leader's behaviour, and routinized charisma, which is associated with the formal position in which a leader is employed. Researchers emphasized the need of eliminating the magical aura from charisma. According to recognized models of research, the emphasis should be on clearly observable behavioral processes that can be defined and studied in detail.

Inspirational motivation, that also occurs when a make open followers by boosting the importance of the work upon themselves by addressing their needs, trying to express their strong convictions, leading by example with high morality and principles, and acting as role models to high morality and principles without the desire for any personal benefit; and idealised influence, which occurs when a leader encourages supporters by enhancing the value of their work to themselves by acting as role models with high morality and principles with out desire for any personal gain. The study of leadership has been tackled from a variety of angles by researchers. Each technique, on the other hand, views leadership as a two-way process in which the charismatic figure exerts extraordinary influence and encourages his or her followers to reach their greatest potential under his or her supervision ${ }^{[3]}$.

\section{Charisma as well as Charismatic Leadership:}

Visionary leaders motivate their people to go above and beyond their duties, even to the point of making personal sacrifices, for the greater good. According to Weber, the charismatic frontrunner's 'transcendentalism goals or path of actions' may or not appeal to potential followers on its own, but it is represented upon because the factions feel their leader is exceptionally talented. The consequence of this discovery seems to be that they are motivated more by the leader than by the goal itself. These leaders have a "quantitatively bigger and qualitatively unique" influence on their followers than their colleagues, which frequently leads to the followers building an emotional connection to them.

Home discovered five main sorts of actions that set charismatic leaders out from the pack. Examples include effective role modeling, actions that build views of achievement as well as competence, the creation of ideologically objectives, the transmission of high anticipations, followers' assurance, and inspiring behaviors. Customers of the company as well as memberships of the general publics are treated as supporters of the leaders in this research, which increases the significance of the leader's charismas. This is the case because the leader's viewpoint is based on how he or she seems from afar, where leaders may attract and captivate followers by encouraging followers as well as providing a vision 
of a perfect upcoming for everybody to see, together of which are charismatic management attributes.

\section{Influence of A Leader's Motivations:}

Numerous research scholars have indicated that leaders' motives have an influence on their businesses' efficiency and performance. Rendering to a investigation by incentive theorists, bosses with a strong drive for success perform better in empire-building responsibilities, such as starting new firms and so on, as well as roles that need personal donations. In two independent investigations, researchers revealed that highly successful CEOs had stronger drive for power than their less successful colleagues.

According to research into the probable links among motivations, charisma, and successful leadership, a specific personality type known as the "leadership motivational profile" is more favorable to leadership success. This implies a moderate-to-high demand for strength, as well as a high degree of action inhibition and a low desire to join. This profile may be expanded to include a desire to form strong networks and play in the game of influence, as well as an interest in influencing and effecting people, and frequently directing their activities ${ }^{[4]}$.

The exhibition of this need for strength, which serves to avoid any impulsive decisionmaking and group thinking in the passage, balances action inhibitions. You can see how the notion of "responsible leadership" enters the picture when you examine the moderating influence of this constraint of action on the desire for power. Through the leadership of persons with higher activities inhibitions, authority is used to pursue institutional rather than own aims.

Inhibition of behavior is measured by the frequency with which the word 'not' is used, which is considered a measure of self-control. Houses as well as Howell found that "character qualities are extremely probable to be charismatic leadership backgrounds" in a similar vein. They find that a higher desire for power is a feature of a charismatic frontrunner after completing a thorough analysis of existing studies. House has proposed a notion that one of the characteristics that distinguishes a charismatic leader from others is a "strong drive to exercise control over others" since 1976".

\section{Impression Management:}

Impressions control as well as dramaturgy is a 'intended effort (people) to influences their perceptions of other people.' This includes guiding such activities to maintain desirable perspectives with others. While decisions making should concentrate on knowledge as well as facts, managers must operate in complicated business circumstances with inadequate information. Such swift judgments and spontaneous actions include 'the 
managers' formal experience, which serves as the foundation for future inferences.' To a certain extent, managers' success relies on their ability to control themselves ${ }^{[5]}$.

The performer, the crowd, the stage, the script, his stage, and the feedback all play a role in performance management. Artists may "set the tone," or in other words, take use of the circumstances to achieve their objectives. A familiar setting generates a collection of perceptions over time. In less familiar settings, performers may organize their performance. In addition to the six forceful print management strategies provided by the playwright model, we draw on the analysis of Sharma's and Grant's literature for this research and added more print management ways as recommended by the authors in their comprehensive model. Graduation attempts to make a goal more attractive; verbal flattery, praise, compliance, smiles and frequently the aim is positive, even fake conduct, like dressing up well, is employed.

Self-promotion may be accomplished via self-improvement and entitlements. Selfimprovement implies that one's ideal characteristics are emphasized and shown extremely positively while the right is utilized to maximize the seeming responsibility for the good outcomes of the actor. Intimidation is frequently employed as a control technique in circumstances in which one person must fear another, in situations in which the target is either unable to repress or has no intention of repressing, and the intimidator does not bother himself with the goal[6].

Examples imply that you portray yourself as a role model. Exemplifying activities, for example, include personal honesty, a willingness to take risks, as well as selfless commitment for the sake of the firm. When an actors with a real or perceived lacks of expertise attempts to evoke sympathy in the minds of a viewer who possesses the needed competence, supplications is usually a last-resorts impression organization approach. However, this renders the artist helpless and vulnerable to the audience's whims.

\section{Leader's Impress Supervision Influence On Charismas:}

Weber underlined the significance of print organization as well as talked about the evidence that the frontrunner must present supporters in order to demonstrate his or her superior qualities. According to House, charismatic leaders may seem to be highly enthusiastic and confident in the moral fairness of their goals, but they have no faith with themselves or their convictions. Because of their ability to act as if they have such conviction strong beliefs, some leaders may well have a captivating impact.

'The truth of history is its importance, not its accuracy,' writes Sharma and Grant, using Gabriel's statement on the 'extension of facts.' Charismatic leaders, according to Weber, rely on "image building" to "produce the appearance of expertise as well as success." Impression management is required for 'idealized influence' and 'inspiring encouragement,' which comprise charismatic leadership, according to theory. 
Exemplification and attributed charisma have a large and positive association, according to study. To put it another way, the research found that charismatic leaders are those who participate in exemplary behavior. Another print management method revealed was intimidation, which was shown to be strongly linked to charismas. The study's outcomes led to the deduction that self-promotions has a negative and considerable impact on a leader's charm. Integration, on the another hands, has been originate to be positively connected to charismas. Ingratiation produces a charismatic image because the leader loves his followers and treats them with kindness and pleasure. Graduating students possess the social skills that a charismatic leader need, such as smiling, complimenting others, and so on ${ }^{[7]}$.

As a result, research shows that most print management practices help leaders conjure charismatic traits, implying that these strategies are related to charisma in followers' minds and aid in the development of a charismatic picture of the leader. House claims that charismatic leaders act in a way that their fans expect them to act in order to explain their behavior. They serve as role models for those taking part in the process. It might also be claimed that charismatic leaders should use print management as an example. According to Fodor and Farrow, those who have a strong need for control are more ingratiated than others.

\section{DISCUSSION}

As a consequence, research indicates that most print management methods assist leaders in conjuring charismatic features, meaning that these strategies are linked to charismas in the eyes of groups and aid in the formation of a charismatic image of the leader. In order to explain their conduct, House says that charismatic leaders behave in the manner that their admirers expect them to perform. They acts as part models for everyone involved in the process. It might also be contended that charismatic executives should set an example in print management. Those who have a high desire for control, according to Fodor and Farrow, are more ingratiated than others.

Transformative leadership is a relationship established on a leader's exceptionality, appeal, and mysticism, which may bring out the best in their followers. Addressing the needs of their followers, expressing their strong beliefs, acting as a role model with high moral and ethical character, and without seeking self-benefit are all ways that transformation leaders have an influence. Transformation leaders inspire and motivate their followers by raising their confidence in their capacity to complete tasks and enhancing the value of their work for themselves. Transformational leadership strengthens the bond between the leader and his or her followers. Another interesting aspect of this study is that supervisors are subservient to their print management strategies, resulting in increased self-efficacy. Given the size of businesses and the 
diverse talent pool with a wide range of talents that faces fierce competition, employees must be extremely self-effective.

Employee empowerment is a goal that all organizations aim towards. Organizations need leaders with exceptional characteristics in order to develop the talents of their personnel. Employees who can successfully influence their superiors as well as promote a healthy and strong commitment to leadership are also desired by employers. Charismatic companies that drive individuals to perform things without expecting anything in return are one of the most significant tools for expanding and employee-friendly businesses.

The goalmouth of this investigation is to examine the influences of transformational leadership on subordinates' self-efficacy, as well as the role of supervisory print management strategies. According to past studies, transformational leadership has a major influence on workplace employee empowerment. By examining the link between subordinates' self-efficacy and print management techniques, this research brings a fresh viewpoint. It analyzes the influence of transformative leadership on subordinates' selfefficiency in the context of print management systems.

\section{CONCLUSION}

Employee participation is a goal that all businesses strive towards. In order to develop the abilities of their employees, organizations need leaders with remarkable qualities. Employers need employees who can effectively influence their superiors and foster a healthy and strong dedication to leadership. One of the most important instruments for developing and employee-friendly firms is charismatic companies that inspire people to do things without expecting anything in return. The determination of this study is to look at how transformational leadership affects subordinates' self-efficacy and how supervisory print management tactics have a role. According to previous research, transformational leadership has a significant impact on employee empowerment in the workplace. This study offers a unique perspective by looking at the relationship between subordinates' self-efficacy and print management practices. In the context of print management systems, it investigates the impact of transformational leadership on subordinates' self-efficiency. 


\section{REFERENCES:}

[1] J. A. Laub, "Assessing the servant organization; Development of the Organizational Leadership Assessment (OLA) model. Dissertation Abstracts International," Procedia - Soc. Behav. Sci., 1999.

[2] E. M. M. H. van Konijnenburg et al., "A mixed methods study on evaluations of Virginia's STEM-focused governor's schools," Diss. Abstr. Int. Sect. B Sci. Eng., 2018.

[3] A. Balick et al., "Identifying poorly met demand: The impact of product beliefs on attribute importance.," J. Mark. Res., 2016.

[4] S. M. Yildiz, "An empirical analysis of the leader-member exchange and employee turnover intentions mediated by mobbing: Evidence from sport organisations," Econ. Res. Istraz. , 2018, doi: 10.1080/1331677X.2018.1432374.

[5] C. H. Yen, C. Y. Chen, J. C. Cheng, and H. Y. Teng, "Brand Attachment, Tour Leader Attachment, and Behavioral Intentions of Tourists," J. Hosp. Tour. Res., 2018, doi: 10.1177/1096348015584438.

[6] V. J. Rosser and J. M. Javinar, "Midlevel Student Affairs Leaders' Intentions to Leave: Examining the Quality of Their Professional and Institutional Work Life," J. Coll. Stud. Dev., 2003, doi: 10.1353/csd.2003.0076.

[7] E. MacIntosh and A. Doherty, "Leader Intentions and Employee Perceptions of Organizational Culture in a Private Fitness Corporation," Eur. Sport Manag. Q., 2005, doi: 10.1080/16184740500089557. 